TRIAL OF MODERNITY 



\section{Trial of Modernity}

Judicial Reform in

Early Twentieth-Century

China, 1901-1937

\section{XIAOQUN XU}

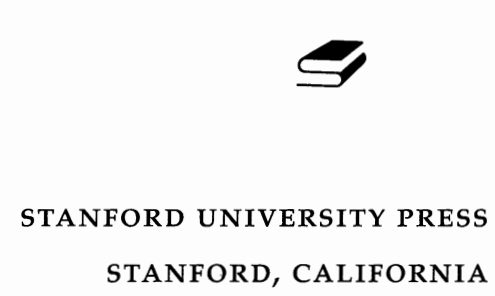




\section{Stanford University Press}

Stanford, California

(C)2008 by the Board of Trustees of the Leland Stanford Junior University. All rights reserved.

Some of the material in this book has appeared in print previously in different form: "Negotiating Western Models and Chinese Practices: Judicial Reform in the Late Qing 'New Policy,' 1901-1911" was originally published in As China Meets the World: China's Changing Position in the International Community, edited by Susanne Weigelin-Schwiedrzik, Agnes Schick-Chen, and Sascha Klotzbücher, @2006, Verlag der Österreichischen Akademie der Wissenschaften. Reprinted with permission. "The Rule of Law Without Due Process: Punishing Robbers and Bandits in EarlyTwentieth-Century China" was originally published in the journal Modern China (vol. 33, no. 2), (C2007, Sage Publications. Reprinted with permission.

No part of this book may be reproduced or transmitted in any form or by any means, electronic or mechanical, including photocopying and recording, or in any information storage or retrieval system without the prior written permission of Stanford University Press.

Library of Congress Cataloging-in-Publication Data $\mathrm{Xu}$, Xiaoqun

Trial of modernity : judicial reform in early twentieth-century China, 1901-1937 / Xiaoqun Xu.

p. $\mathrm{cm}$.

Includes bibliographical references and index.

ISBN 978-0-8047-5586-3 (cloth : alk. paper)

1. Justice, Administration of-China-History. 2. Law reformChina-History. I. Title.

KNN1572.x89 2008

$340^{\prime} .3095109041-\mathrm{dc22}$

Typeset at Stanford University Press in 10/12.5 Palatino 
For

My Parents 
